\title{
Taxonomic studies on the genus Isotrema (Aristolochiaceae) from China III: I. pseudohei, a new species from Yunnan, Southwest China
}

\author{
Jun Wang ${ }^{1 \dagger}$, Guo-Dong $\mathrm{Li}^{2 \dagger}$, Juan-Juan Yang', \\ Bin Shen ${ }^{3}$, Chun-Xia $\mathrm{Pu}^{2}$, Xin-Xin Zhu'
}

I College of Life Sciences, Xinyang Normal University, Xinyang 464000, Henan, China 2 Faculty of Traditional Chinese Pharmacy, Yunnan University of Chinese Medicine, Kunming 650500, Yunnan, China 3 Shanghai Zuibaichi Park, Shanghai 201600, China

Corresponding author: Xin-Xin Zhu (zhuzhu8niuniu@126.com)

Academic editor:Elton John deLirio | Received 24January 2021| Accepted25October 2021 | Published6December 2021

Citation: Wang J, Li G-D, Yang J-J, Shen B, Pu C-X, Zhu X-X (2021) Taxonomic studies on the genus Isotrema (Aristolochiaceae) from China III: I. pseudohei, a new species from Yunnan, Southwest China. PhytoKeys 186: 43-52. https://doi.org/10.3897/phytokeys.186.63543

\begin{abstract}
Isotrema pseudohei, a new species from Yunnan, Southwest China, is described and illustrated. It is morphologically similar to $I$. hei and I. moupinense, but differs from the former in the colour of flower and throat, the size of throat and the shape of gynostemium lobes, and from the latter in the shape of lamina and gynostemium lobes.
\end{abstract}

\section{Keywords}

Aristolochia, clarification, morphology, taxonomy

\section{Introduction}

Isotrema Raf. was previously treated as a subgenus of Aristolochia L. and was recently reinstated as an independent genus base on both molecular data and morphological evidence (Zhu et al. 2019a). It can be distinguished from the genus Aristolochia in the strongly curved perianth with a 3-lobed limb, and especially the 3-lobed gynostemium with a pair of anthers on the outer surface of each gynostemium segment. Comprising 109 species,

$\dagger$ These authors contributed equally to this work.

Copyright Jun Wang et al. This is an open access article distributed under the terms of the Creative Commons Attribution License (CC BY 4.0), which permits unrestricted use, distribution, and reproduction in any medium, provided the original author and source are credited. 
the genus mainly occurring in East and South Asia, with a few species disjunctly distributed in North and Central America (Zhu et al. 2019a). Currently, 71 species of Isotrema are recorded in China, of which 57 are endemic (Hwang et al. 2003; Lai et al. 2019; Li et al. 2019; Peng et al. 2019; Zhou et al. 2019; Zhu et al. 2019a, 2019b, 2019c, 2019d, 2019e; Cai et al. 2020a, 2020b; Luo et al. 2020; Wang et al. 2020a, 2020b; Liao et al. 2021).

During a field expedition to Yunnan, Southwest China, some unknown specimens of Isotrema were discovered. After careful comparison with previously known species and study of related literature (Hwang 1988; Ma 1989a, 1989b; Tao 1997; Hwang et al. 2003; Do et al. 2015; Do and Nghiem 2017; Yang et al. 2018; Zhu et al. 2019a, 2019d; Cai et al. 2020a, 2020b; Wang et al. 2020a, 2020b), we confirm it as a new species, describe and illustrate it below.

\section{Material and methods}

Specimens of Isotrema from 36 herbaria (A, BM, BR, CDBI, CSFI, CSH, E, EMA, GXMI, HAST, HENU, HHBG, HIB, HITBC, IBK, IBSC, K, KUN, L, LBG, LE, NAS, NTUF, P, PE, PEM, QTPMB, SM, SNU, SYS, TAI, W, WCU, WU, WUK, YUKU; acronyms follow Thiers 2021) and our collections in the field all over Asia were examined. Meanwhile, the literature, in particular the protologues of published names, was collated and reviewed. The geographic distribution has been compiled from literatures and complemented by the analyzed specimens and color photos. Photographs of plants were taken in the wild for each species and the terminology of description was mainly based on the Flora of China (Hwang et al. 2003).

\section{Taxonomy}

Isotrema pseudohei X.X.Zhu, Jun Wang bis \& G.D.Li, sp. nov. urn:Isid:ipni.org:names:77234089-1

Figures $1-3,4 \mathrm{~A}-\mathrm{C}$

Type. China. Yunnan: Yuxi City, Xinping County, near Atizuo Village, $101^{\circ} 55^{\prime} 51^{\prime \prime E}$, $23^{\circ} 58^{\prime} 46 " \mathrm{~N}, 1823 \mathrm{~m}$ a.s.l., 11 September 2018, X. X. Zhu et al. ZXX18249 (holotype: CSH [CSH-0157854!]; isotypes: CSH!, KUN!).

Diagnosis. Similar to Isostrema hei Lei Cai \& X.X.Zhu and I. moupinense (Franch.) X.X.Zhu, S. Liao \& J.S.Ma, but significantly differs in the following characters: laminas lanceolate to narrowly lanceolate, basal tube of calyx ca. $1.5 \mathrm{~cm}$ long, inside dark purple at base and yellowish white above base; upper tube of calyx ca. $2.3 \mathrm{~cm}$ long, inside yellowish white, getting yellow in upper portion; inner surface of limb yellow with purplish red patches; throat yellow, suborbicular, 7-9 $\mathrm{mm}$ in diameter; apex of gynostemium lobes acute.

Description. Climbing shrubs. Stems terete, brown pubescent when young, old branchlets glabrous. Petioles 1-2 cm long, appressed villous; laminas lanceolate to nar- 


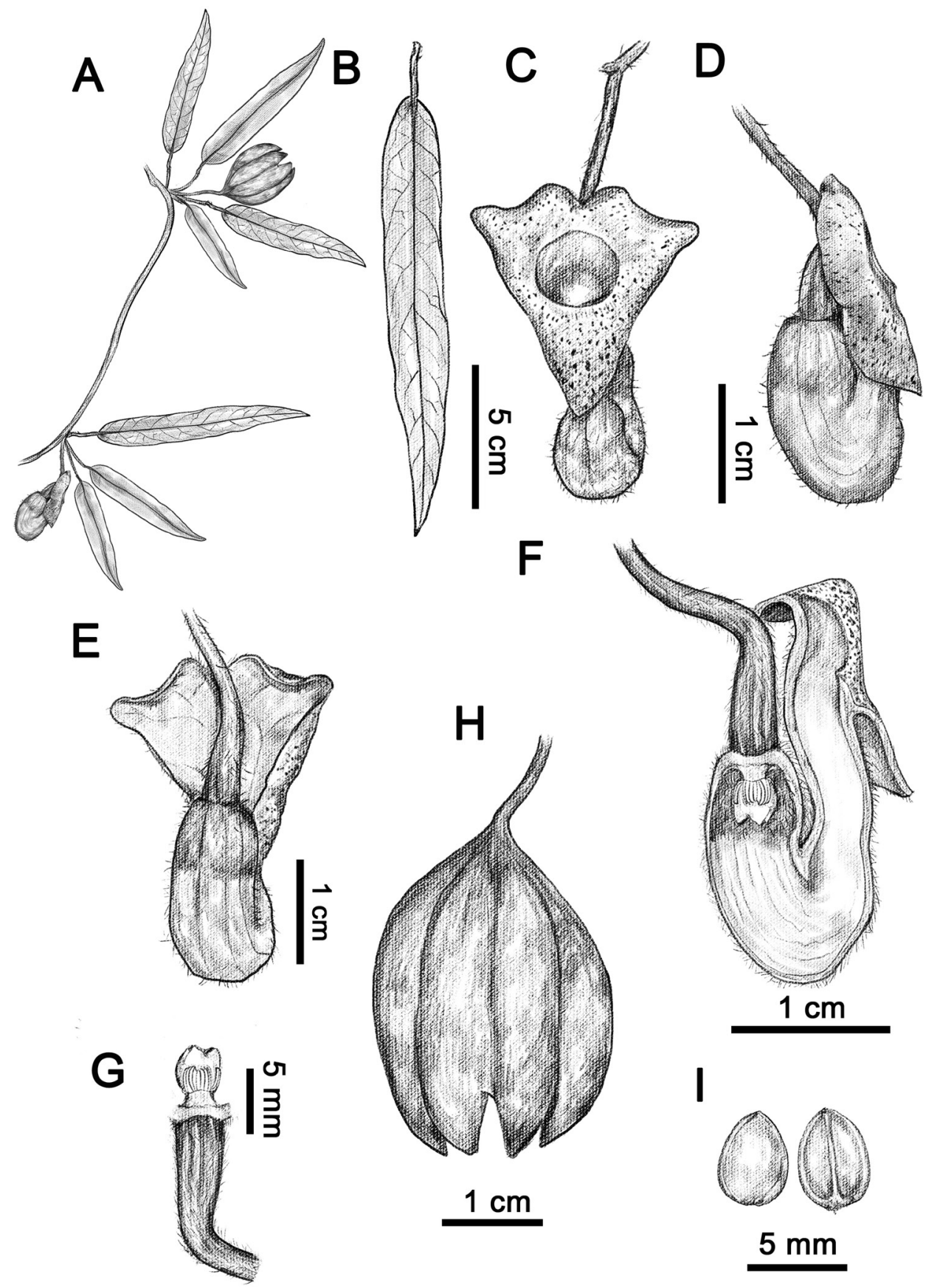

Figure I. Line drawing of Isotrema pseudohei X.X.Zhu, Jun Wang bis \& G.D.Li A habit B leaf C flower (frontal view) D flower (lateral view) E flower (dorsal view) F dissected flower (showing the inside structure) $\mathbf{G}$ anthers and gynostemium $\mathbf{H}$ dehiscing capsule $\mathbf{I}$ seeds. Illustrated by Shi-Zhen Qiao. 


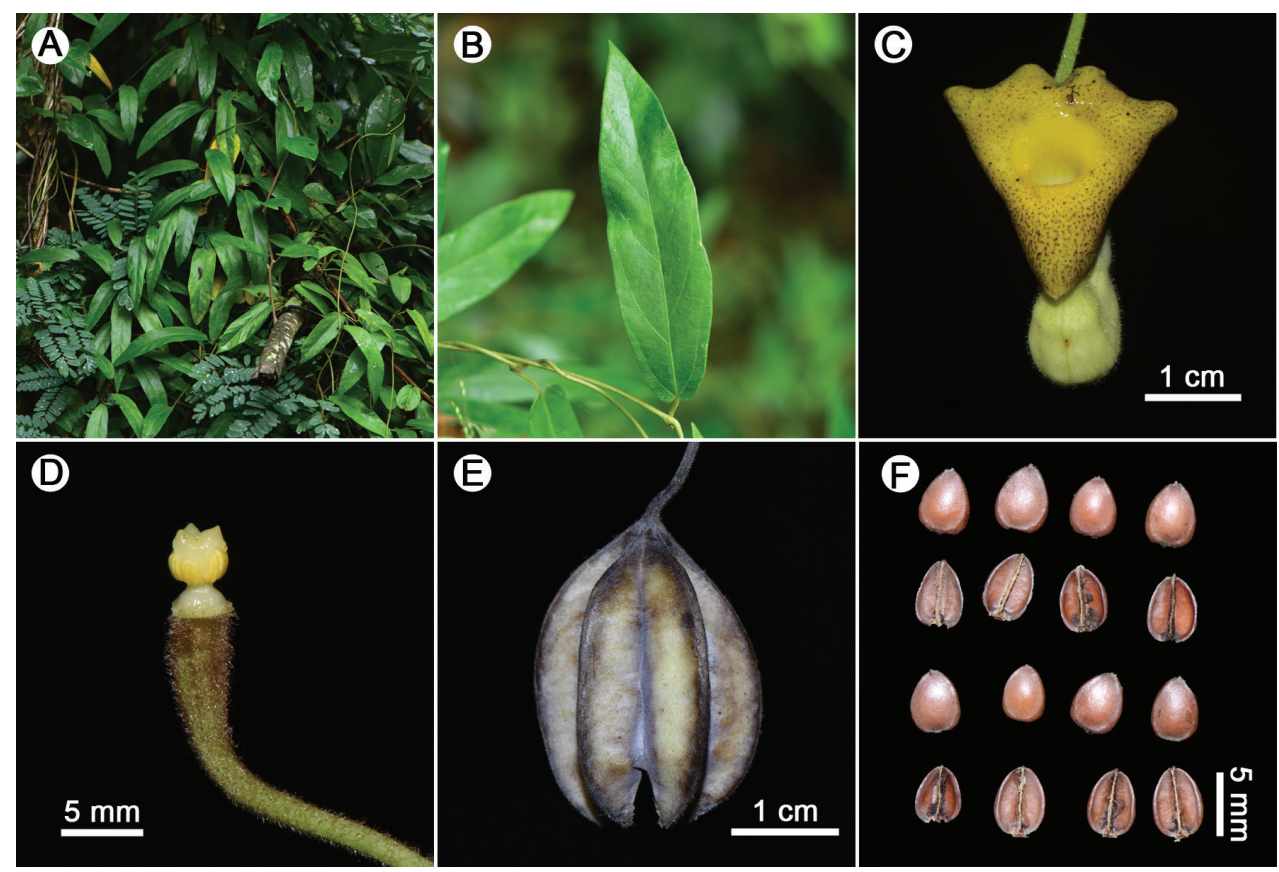

Figure 2. Isotrema pseudohei X.X.Zhu, Jun Wang bis \& G.D.Li from the type locality A habit B leaves C flower (frontal view) D anthers and gynostemium E fruit $\mathbf{F}$ seeds. Photographed by Xin-Xin Zhu.

rowly lanceolate, $6.5-17.5 \times 2.6-4.5 \mathrm{~cm}$, base round to shallowly cordate, margin entire, apex acute, adaxially sparsely pubescent, abaxially densely villous, especially on veins, lateral veins 4-6-paired. Flower solitary, axillary or on stems; pedicels ca. $3 \mathrm{~cm}$ long, densely rusty villous; bractlet 1 , lanceolate to elliptic, $3-4 \mathrm{~mm}$ long, adaxially subglabrous, abaxially densely rusty villous, inserted on middle part of pedicel. Calyx tube geniculately curved, abaxially yellowish white, densely villous; basal tube ca. $1.5 \mathrm{~cm}$ long, inside dark purple at base and yellowish white above base; upper tube ca. $2.3 \mathrm{~cm}$ long, inside yellowish white, getting yellow in upper portion; limb discoid, ca. $2.1 \mathrm{~cm}$ wide, shallowly 3-lobed, lobes broadly triangular, inner surface yellow with purplish red patches; throat suborbicular, yellow, 7-9 $\mathrm{mm}$ in diameter. Anthers 6, oblong, ca. $1.6 \mathrm{~mm}$ long, adnate in 3 pairs to base of gynostemium, opposite to lobes. Gynostemium 4-5 mm long, 3-lobed, apex of lobes acute. Ovary terete, ca. $8 \mathrm{~mm}$ long, densely brown villous. Capsule cylindric, six arrises, ca. $3 \times 2.2 \mathrm{~cm}$. Seeds ovate to elliptic, $3.5-5 \times 3-4.5 \mathrm{~mm}$, adaxially deeply concave, abaxially convex, glabrous on both sides.

Phenology. Flowering and fruiting specimens of the new species were collected in September.

Etymology. The specific epithet refers to the similarity between the new species and Isotrema hei in the morphology of lamina and flower. The Chinese name is given as “拟何氏关木通”。 


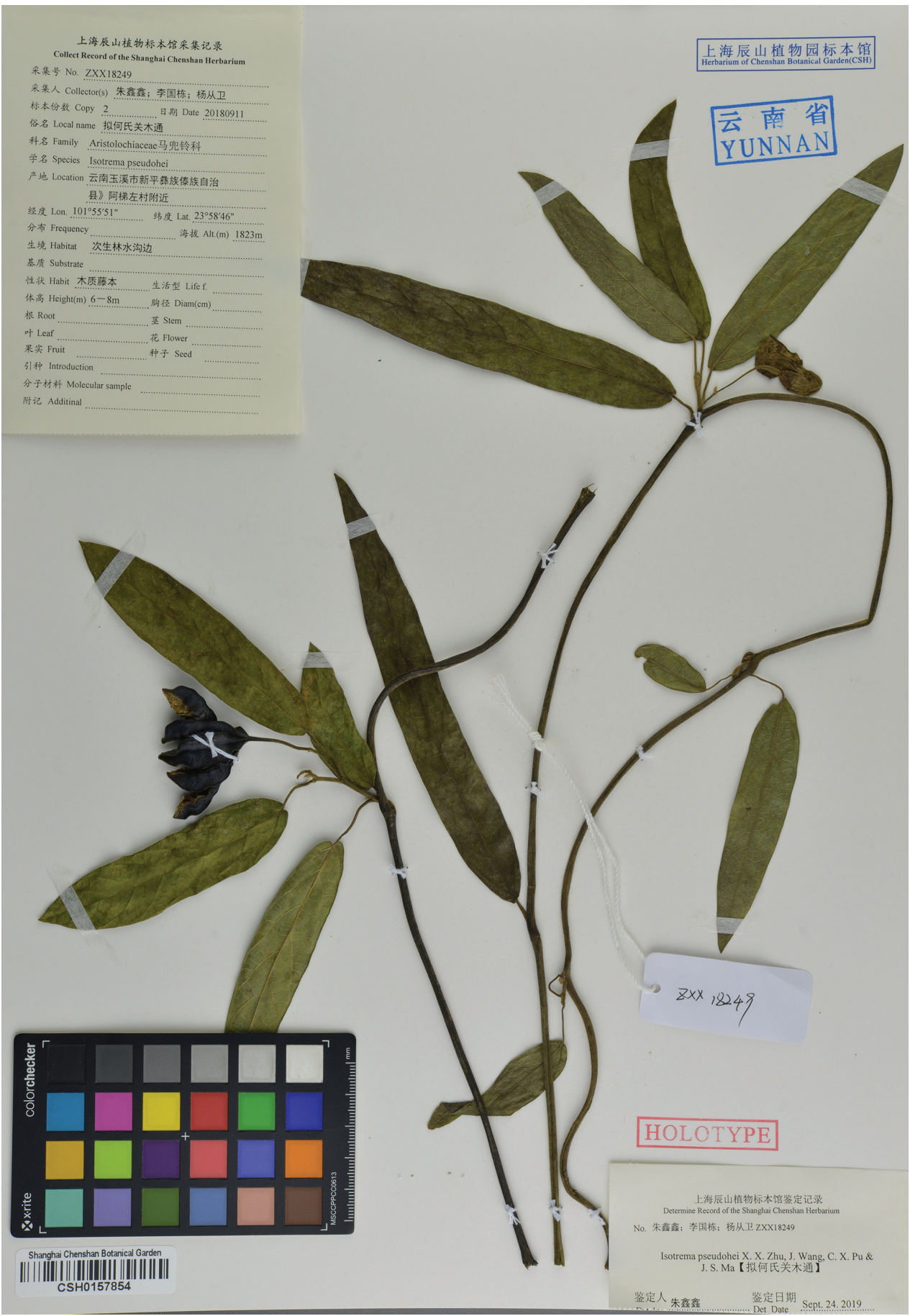

Figure 3. Holotype of Isotrema pseudohei X.X.Zhu, Jun Wang bis \& G.D.Li. (CSH-0157854). 
Distribution and habitat. Isotrema pseudohei is distributed in Xinping County of Yunnan Province, China. It grows on the roadside or in mixed forests on sunny slopes at an elevation between $1820 \mathrm{~m}$ and $2045 \mathrm{~m}$, together with other taxa as Castanopsis sp. (Fagaceae), Commelina undulata R. Br. (Commelinaceae), Disporum sp. (Colchicaceae), Lycianthes macrodon (Wall.) Bitter (Solanaceae), Rubus sp. (Rosaceae), etc.

Preliminary conservation status. Isotrema pseudohei is currently only known from two populations in Xinping County, with fewer than five individuals at each site. Based on the present study, its Extent of Occurrence (EOO) is less than $100 \mathrm{~km}^{2}$ and the known Area of Occupancy (AOO) is less than $20 \mathrm{~km}^{2}$. Furthermore, the habitat is being destroyed by road construction and small-scale agriculture. Besides, the root of Isotrema itself is often harvested for medicinal purposes by the locals. Although further investigation is necessary to fully map its distribution, it is considered to be Vulnerable (VU) status, based on the criteria D2 of IUCN according to the IUCN Red List Categories and Criteria (IUCN Standards and Petitions Committee 2019).

Additional specimens of Isotrema pseudohei examined (paratypes). CHINA. Yunnan: Yuxi City, Xinping County, 2045 m a.s.l., 11 September 2018, X. X. Zhu et al. ZXX18250 (CSH, KUN).

Specimens of Isotrema hei examined. China. Yunnan: Wenshan City, 12 May 2018, X. X. Zhu ZXX18072 (CSH), 20 April 2018, Lei Cai et al. CL115 (KUN).

Specimens of Isotrema moupinense examined. CHINA. Chongqing: Nanchuan District, 27 May 1957, T. H. Hsiung \& Z. L. Chou 91052 (IBSC), 11 July 1957, S. Y. Chen et al. 95126 (NAS), 12 July 1957, T. H. Hsiung \& Z. L. Chou 91972 (IBSC), 25 July 1957, T. H. Hsiung \& Z. L. Chou 92285 (IBSC), 17 May 2007, Z. B. Feng et al. 20070508 (PE, WCSBG); Sichuan: Baoxing County, 4 August 1936, K. L. Qu 3410 (IBSC), 1954, T. P. Soong, 38982 (IBSC, NAS), 20 May 1958, Sichuan Agricultural College 4867 (IBSC); Dayi County, 26 May 2015, X. X. Zhu \& Z. X. Hua ZHO82 (CSH), 26 May 2015, X. X. Zhu \& Z. X. Hua ZH083 (CSH); Emeishan City, 1952, C. H. Hsiung et al. 30475 (IBK, IBSC, NAS), 24 May 1952, C. H. Hsiung et al. 30750 (IBSC), 6 June 1960, Sichuan Med. Pl. Exped. 12729 (NAS), 29 April 2015, X. X. Zhu \& Z. X. Hua ZHO46 (CSH); Jinyang County, 29 April 2013, C. Du \& Y. Wang DC-325 (CSH); Luding County, 14 July 2006, X. M. Gao G06117(WCSBG); Yingjing County, 20 May 1940, K. L. Chu 6901 (NAS); Yunnan:Gongshan County, 25 May 2011, J. Cai et al. 11 CS2767 (KUN); Yunlong County, 24 April 2019, X. X. Zhu et al. ZXX19356(KUN).

\section{Discussion}

Characterized by a horseshoe-shaped perianth and a 3-lobed gynostemium with each lobe consisting of two oblong stamens, the new species is shown to be a member of Isotrema (Zhu et al. 2019a). Isotrema pseudohei is similar to I. hei in the shape of lamina (Fig. 4A \& D), but differs in the morphology of flowers, the inner surface of limb is yellow with purplish red patches and throat suborbicular, yellow, and 7-9 $\mathrm{mm}$ in diameter in I. pseudohei (Figure 4C), whereas the inner surface of limb yellowish 


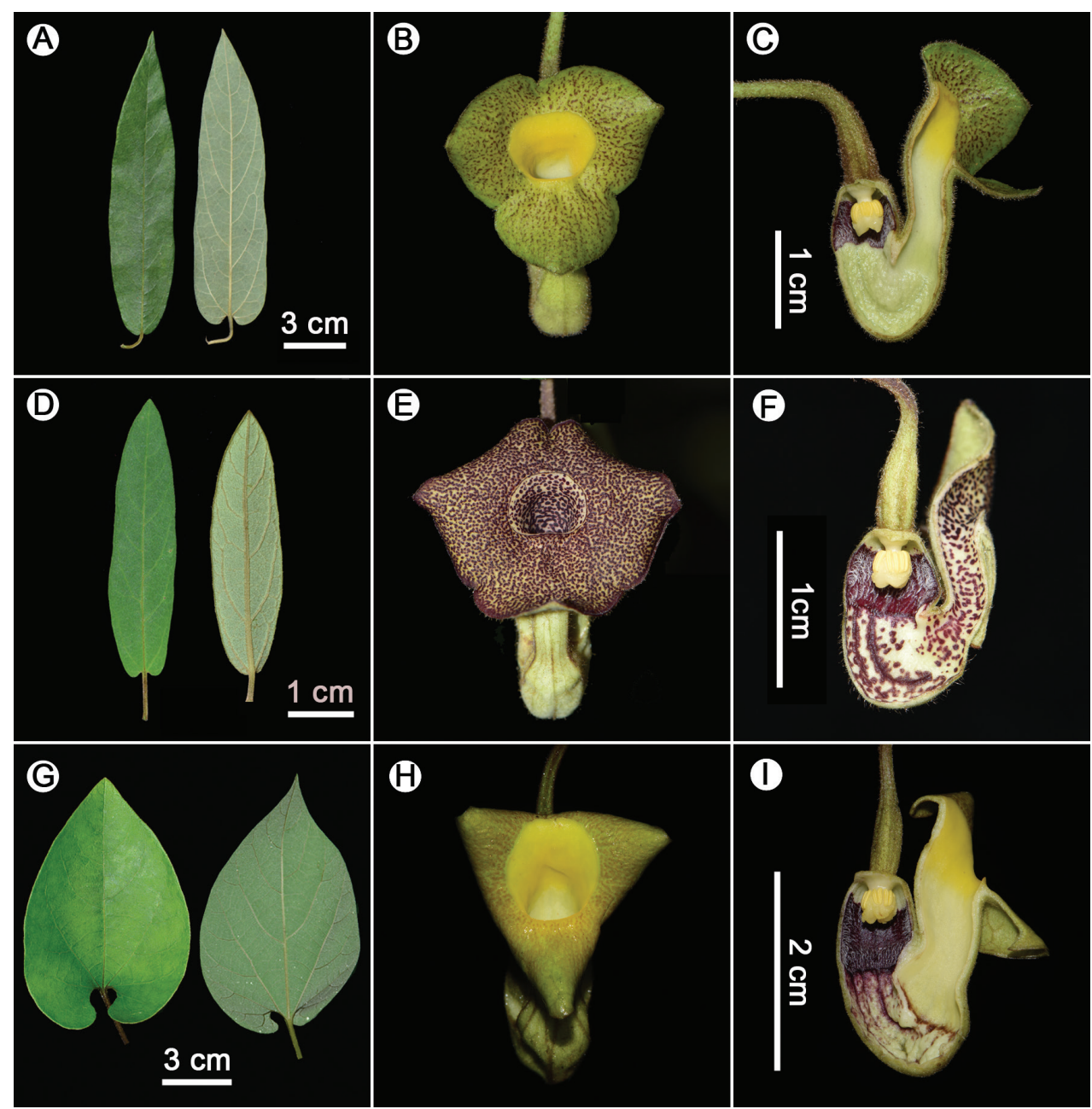

Figure 4. Morphological comparisons of the leaves and flowers of Isotrema pseudohei (A-C), I. hei (D-F) and I. moupinense (G-I). Photographed by Xin-Xin Zhu.

green and densely covered with purple papillae and throat circular, yellowish green with purple patches, and 4-5 $\mathrm{mm}$ in diameter in $I$. hei (Figure 4F). Though sharing similar morphology of flowers (Fig. 4B, C, H, J), I. pseudohei can be easily distinguished from I. moupinense by the shape of lamina, which is lanceolate in the new species (Figure 4A), but ovate in I. moupinense (Figure 4G). Moreover, I. pseudohei also differs in the gynostemium lobes acute at apex (Figures 2D \& 4C), whereas round at apex in $I$. hei (Figure 4F) and I. moupinense (Figure 4I). Detailed morphological comparisons are provided in Table 1 and shown in Figure 4. Geographically, the new species is currently only known from Xinping County in central Yunnan, I. hei is restricted to Wenshan City in Southeast Yunnan, while I. moupinense is widely distributed in Southwest China (Figure 5). 


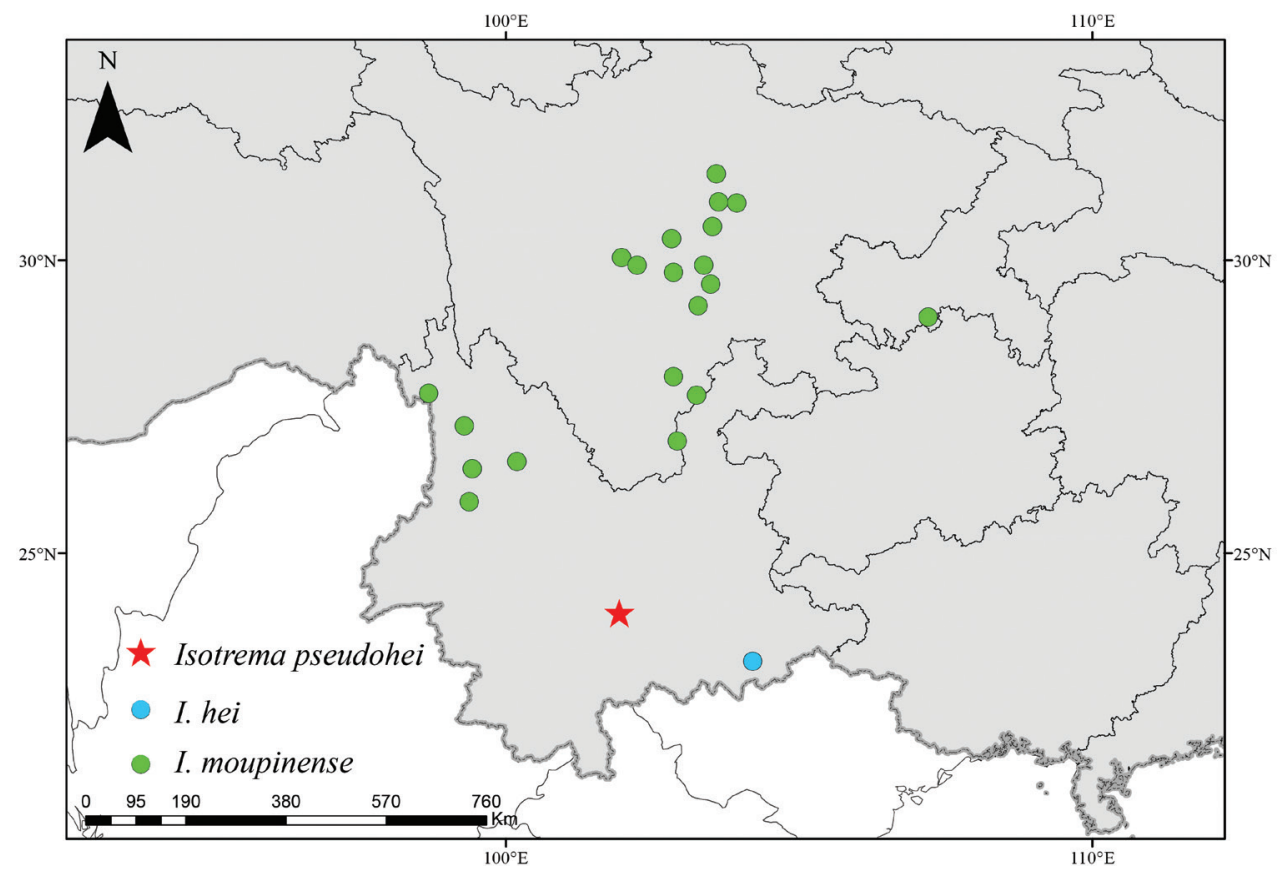

Figure 5. Distribution of Isotrema pseudohei, I. hei and I. moupinense based on field observation, specimens, color photos and literatures examined.

Table I. Morphological comparisons of Isotrema pseudohei, I. hei and I. moupinense.

\begin{tabular}{|c|c|c|c|}
\hline Character & I.pseudohei & $\begin{array}{l}\text { I. hei } \\
\end{array}$ & I. moupinense \\
\hline Lamina & $\begin{array}{c}\text { lanceolate to narrowly lanceolate, } \\
6.5-17.5 \times 2.6-4.5 \mathrm{~cm}\end{array}$ & $\begin{array}{l}\text { lanceolate to narrowly lanceolate or } \\
\text { narrowly elliptic, } 2.5-12.5 \times 1-4.5 \mathrm{~cm}\end{array}$ & ovate, $6-16 \times 5-12 \mathrm{~cm}$ \\
\hline Basal tube of calyx & $\begin{array}{l}\text { inside dark purple at base and } \\
\text { yellowish white above base }\end{array}$ & $\begin{array}{l}\text { inside dark purple at base and yellowish } \\
\text { white with dark purple stripes and } \\
\text { patches above base }\end{array}$ & $\begin{array}{l}\text { inside dark purple at base and } \\
\text { yellowish with purple stripes } \\
\text { and patches above base }\end{array}$ \\
\hline Upper tube of calyx & $\begin{array}{l}\text { inside yellowish white, getting } \\
\text { yellow in upper portion }\end{array}$ & $\begin{array}{l}\text { inside yellowish white with reddish } \\
\text { purple patches }\end{array}$ & $\begin{array}{l}\text { inside yellowish white, getting } \\
\text { yellow in upper portion }\end{array}$ \\
\hline Limb & $\begin{array}{l}\text { ca. } 2.1 \mathrm{~cm} \text { wide; inner surface } \\
\text { yellow with purplish red patches }\end{array}$ & $\begin{array}{c}\text { ca. } 2.4 \mathrm{~cm} \text { wide; inner surface yellowish } \\
\text { green and densely covered with purple } \\
\text { papillae }\end{array}$ & $\begin{array}{l}2-2.5 \mathrm{~cm} \text { wide; inner surface } \\
\text { yellow to dark red, sometimes } \\
\text { with red or yellow spots }\end{array}$ \\
\hline Throat & $\begin{array}{c}\text { suborbicular, yellow, 7-9 } \mathrm{mm} \text { in } \\
\text { diameter }\end{array}$ & $\begin{array}{l}\text { circular, yellowish green with purple } \\
\text { patches, } 4-5 \mathrm{~mm} \text { in diameter }\end{array}$ & $\begin{array}{c}\text { circular, yellow, } 8-11 \mathrm{~mm} \text { in } \\
\text { diameter }\end{array}$ \\
\hline Gynostemium & apex of lobes acute & apex of lobes round & $\begin{array}{l}\text { apex of lobes usually bilobate, } \\
\text { rarely obtuse }\end{array}$ \\
\hline
\end{tabular}

\section{Acknowledgements}

The authors would like to thank Ms. Shi-Zhen Qiao for the line drawing of the new species. This study was supported by the Special Subsidies for Public Health Services of "Fourth Chinese Materia Medica Resources Survey" (DSS, MOF.43/2018) and the Institute for Conservation and Utilization of Agro-bioresources in the Dabie Mountains. 


\section{References}

Cai L, Dao ZL, Zhu XX (2020a) Isotrema hei (Aristolochiaceae), a new species from southeastern Yunnan, China. Annales Botanici Fennici 57(1-3): 125-129. https://doi. org/10.5735/085.057.0117

Cai L, He DM, Huang YS, Dao ZL (2020b) Aristolochia wenshanensis, a new species of Aristolochiaceae from karst region in southeastern Yunnan, China. Taiwania 65: 41-46. https://doi.org/10.6165/tai.2020.65.41

Do TV, Nghiem TD (2017) Taxonomic notes on some Aristolochia species in Vietnam. Taiwania 62: 216-218. https://doi.org/10.6165/tai.2017.62.216

Do TV, Luu TH, Wanke S, Neinhuis C (2015) Three new species and three new records of Aristolochia subgenus Siphisia from Vietnam including a key to the Asian species. Systematic Botany 40(3): 671-691. https://doi.org/10.1600/036364415X689140

Hwang SM (1988) Aristolochia Linnaeus. In: Kiu HS, Ling YR (Eds) Flora Reipublicae Popularis Sinicae 24. Science Press, Beijing, 199-245.

Hwang SM, Kelly LM, Gilbert MG (2003) Aristolochia Linnaeus. In: Wu ZY, Raven PH, Hong DY (Eds) Flora of China, Vol. 5. Science Press, Beijing \& Missouri Botanical Garden Press, St. Louis, 258-269.

IUCN Standards and Petitions Committee (2019) Guidelines for Using the IUCN Red List Categories and Criteria. Version 14. http://www.iucnredlist.org/documents/RedListGuidelines.pdf [accessed 15 May 2021]

Lai HV, Nguyen TT, Do TV (2019) Aristolochia mulunensis (Aristolochiaceae), a New Record and Notes on Taxonomy, Distribution of some Aristolochia Species for The flora of Vietnam. VNU Journal of Science: Natural Sciences and Technology 35: 1-7. https://doi. org/10.25073/2588-1140/vnunst.4867

Li RT, Wang ZW, Wang J, Zhu XX, Xu H (2019) Isotrema sanyaense, a new species of Aristolochiaceae from Hainan, China. PhytoKeys 128: 85-96. https://doi.org/10.3897/phytokeys.128.35042

Liao S, Zhu XX, Yan J, Du C, Li HQ (2021) The valid publication and identity of Aristolochia compressicaulis (Aristolochiaceae). Phytotaxa 513(1):75-79. https://doi.org/10.11646/phytotaxa.513.1.6

Luo YJ, Ni SD, Jiang Q, Huang BG, Liu Y, Huang YS (2020) Aristolochia yachangensis, a new species of Aristolochiaceae from limestone areas in Guangxi, China. PhytoKeys 153: 49-61. https://doi.org/10.3897/phytokeys.153.52796

Ma JS (1989a) A revision of Aristolochia Linn. from E. \& S. Asia. Zhiwu Fenlei Xuebao 27: 321-364.

Ma JS (1989b) A revision of Aristolochia from Yunnan. Yunnan Zhi Wu Yan Jiu 11: 321-323.

Peng YL, Gadagkar SR, Li J, Xie YY, Huang XY, Lu HZ, Huang BY, Yu LY (2019) Aristolochia kechangensis sp. nov. (Aristolochiaceae) from Guangxi, China. Nordic Journal of Botany 37(9): 1-7. https://doi.org/10.1111/njb.02456

Tao DD (1997) Aristolochia Linnaeus. In: Chen SK (Ed.) Flora Yunnanica 8. Science Press, Beijing, 7-25.

Thiers B (2021) Index Herbariorum: A global directory of public herbaria and associated staff. New York Botanical Garden's Virtual Herbarium. http://sweetgum.nybg.org/science/ih/ [accessed 15 May 2021] 
Wang J, Ma JS, Zhu XX (2020a) Four new combinations in Isotrema (Aristolochiaceae). Phytotaxa 437(3): 174-176. https://doi.org/10.11646/phytotaxa.437.3.8

Wang J, Ya JD, Liu C, Liu G, Cao F, Ma JS, Zhu XX (2020b) Taxonomic studies on the genus Isotrema (Aristolochiaceae) from China: II. I. brevilimbum (Aristolochiaceae), a new species from Guizhou, China. PhytoKeys 152: 15-25. https://doi.org/10.3897/phytokeys. 152.51760

Yang B, Ding HB, Zhou SS, Zhu XX, Li R, Mya BM, Tan YH (2018) Aristolochia sinoburmanica (Aristolochiaceae), a new species from north Myanmar. PhytoKeys 94: 13-22. https:// doi.org/10.3897/phytokeys.94.21557

Zhou XX, Jiang GB, Zhu XX, Liu ZY, Huang Y, Wang GT, Wang RJ (2019) Isotrema plagiostomum (Aristolochiaceae), a new species from Guangdong, South China. Phytotaxa 405(4): 221-225. https://doi.org/10.11646/phytotaxa.405.4.7

Zhu XX, Li XQ, Liao S, Du C, Wang Y, Wang ZH, Yan J, Zuo YJ, Ma JS (2019a) Reinstatement of Isotrema, a new generic delimitation of Aristolochia subgen. Siphisia (Aristolochiaceae). Phytotaxa 401(1): 1-23. https://doi.org/10.11646/phytotaxa.401.1.1

Zhu XX, Li XQ, Liao S, Li GD, Ma JS (2019b) The taxonomic revision of Asian Aristolochia (Aristolochiaceae) V: Two new species from Yunnan, China. PhytoKeys 130: 93-106. https://doi.org/10.3897/phytokeys.130.33933

Zhu XX, Liao S, Tan YH, Shen JY, Ma JS (2019c) Aristolochia bhamoensis is a taxonomic synonym of $A$. tongbiguanensis, and now the correct name is Isotrema tongbiguanense. Phytotaxa 404(7): 292-294. https://doi.org/10.11646/phytotaxa.404.7.3

Zhu XX, Wang J, Liao S, Ma JS (2019d) Synopsis of Aristolochia L. and Isotrema Raf. (Aristolochiaceae) in China. Shengwu Duoyangxing 27(10): 1143-1146. https://doi. org/10.17520/biods.2019183

Zhu XX, Zheng HL, Wang J, Gao YQ, Ma JS (2019e) Taxonomic studies on the genus Isotrema (Aristolochiaceae) from China: I. I. cangshanense, a new species from Yunnan. PhytoKeys 134: 115-124. https://doi.org/10.3897/phytokeys.134.37243 